\title{
乳幼児斜視のボツリヌム療法と両眼視機能獲得
}

\author{
新井紀子 ${ }^{1 ｝ \cdot \text { 深井小久子 }{ }^{2)} \cdot \text { 椎原久美子2) }$ \\ 早川友恵 ${ }^{2)} \cdot$ 木村 久 ${ }^{12}{ }^{21}$ \\ 1）（川崎医科大学 眼科学教室） \\ 2）（川崎医療福祉大学 感覚矯正学科）
}

\section{Improvement of Binocular Function after Treatment of Infantile Esotropia with Botulinum Toxin.}

\author{
Noriko Arai ${ }^{1)}$, Sakuko Fukai ${ }^{2)}$, Kumiko Shiihara ${ }^{1)}$ \\ Tomoe Hayakawa ${ }^{1)}$, Hisashi Kimura ${ }^{1)}{ }^{2)}$ \\ 1 ) (Department of Ophthalmology, Kawasaki Medical School) \\ 2 ) (Department of Sensory Sciences, Kawasaki University of Medical Welfare)
}

\begin{abstract}
乳児内斜視に対してボッリヌム療法を行い，両眼視機能獲得状態について検討した。 症例は生後 1 年以内に発症し, 内直筋の過緊張を認める乳児内斜視 30 例である。注入後の経 過観察期間は平均19力月であった。

眼位は平均2.9回のボッリヌム注入後 3 カ月を経ても症例の70\%（21/30例）に安定した 眼位改善が得られた。また，網膜対応は60\%（18/30例）に正常対応化を認めた。両眼視機 能の結果は, 良好 5 例, 改善 5 例, 不良 20 例であり, $34 \%(10 / 30$ 例) に両眼視機能が獲得 できた。

ボッリヌム注入後の眼位変動は両眼視機能獲得を促進することが推定された。すなわち, 一過性の眼位過矯正が異常な方向感覚を打ち消し，頻回注入で安定した良好な眼位が保持で きると新たな視方向が確立し，感覚異常の改善を生じさせる。眼位のコントロールと感覚異 常の改善は, 両眼視機能の獲得を導くと考元た。
\end{abstract}

連絡先： $7701-01$ 倉敷市松島 577

川崎医科大学眼科学教室（TEL 0864-62-1111 内線 3730）

新井 紀子（あらい のりこ）

Key words : Botulinum toxin, infantile esotropia binocular function, retinal correspondence 
We studied the influence of the ocular alignment effect of botulinum toxin on the binocular function of infantile esotropia.

The subjects were 30 cases of infantile esotropia, with the onset in infants under 12 months and with contracture of the medial rectus. The average follow up period after injection was 19 months.

Three months after botulinum injection, good eye position was achieved in $70 \%(21 / 30)$, and ARC was normalized in $60 \%(18 / 30)$.

Five cases achieved good stereopsis ( $>/ 9$ : Titmus circle score). Five other cases achieved partial improvement and the other cases showed no change. Binocular function was achieved in $34 \%$ of the cases.

Alteration of the deviation by repetitive botulinum injection caused the improvement of binocularity.

The temporal overcorrection may help to eliminate corresponding points of anomaly. By using botulinum injections frequently, good eye position could be stabilized, and then improved visual directions and normalization of retinal correspondence were established. The results indicated that frequent botulinum injection led to the improvement of binocularity.

\section{I . 緒言}

斜視治療の方法として Scottによってボッリ

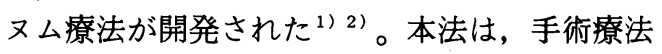
と比較して, 外眼筋を切断することなく筋力を 弱めることができる (chemical recession ${ }^{3)}$ ) た め, 外眼筋の過緊張を認める斜視の治療に用い られ，有用性については数多くの報告がある4) 5）6）7）8。本法の治療前における両眼視機能の 有無は，眼位安定に影響することは述べられて いるが5), 両眼視機能獲得についての詳細な報 告はない。今回, 内直筋の過緊張を認める乳児 内斜視に対して, ボッリヌム療法を行い, 両眼 視機能獲得状態とその予後について検討したの で報告する。

\section{II . 症例および方法}

\section{1. 症例}

症例は, 生後 1 年以内に発症し, 内直笳の過 緊張を認める乳児内斜視30例で, 次の 2 グルー プに分けた。第 1 群は, 斜視手術後の残余内斜 視にボツリヌム療法を行った24例である。注入 前の斜視角は、 $6 \sim 60 \Delta$ (平均 $28 \Delta$ ) であった。 手術後からボッリヌム療法までの期間は 1 か月
〜15年であった。また両眼視機能は23例が不能 であり，1例のみ 140 seconds の立体視を保持し ていた。第 2 群は, ボッリヌム療法のみ行った 6 例である。注入前の斜視角は，20〜70 $\Delta$ （平 均39 $\Delta$ ）で, 両眼視機能は全例不能であった。

全症例のボッリヌム療法開始年齢は $3 \sim 22$ 歳 で, 平均8.2歳であった。注入後の経過観察期 間は $5 \sim 30$ か月で平均19か月であった。

\section{2. 方法}

ボッリヌムの注入方法は, Scott 原法の $1 / 10$ 〜 1/5の用量 (0.25 0.5U) で開始し, 経過を みながら再注入毎に増量した。注入は過緊張の 認められる内直筋に対して $1 \sim 5$ 回の頻回注入 を行った。

効果の判定は最終注入時より 3 力月以降に, 斜視角・両眼視機能・網膜対応状態により行 った。斜視角は, Krimsky 法又は prism cover testにより測定した。両眼視機能は, Titmus stereo tests $の$ circle score（以下チトマススコ アと略す) 7 9/9を良好, 4 6/9を改善, 0 3/9 を不良として判定した。網膜対応は Bagolini striated glass (以下 S G test と略す), Synoptophore test, 残像法により総合判定を行った。す なわち，すべての検査法で正常パターンが得ら 
れるものを正常対応（以下 N R C と略す）, $\mathrm{S}$ $\mathrm{G}$ test などの分離度の浅い検查法で N R C を 示すタイプを正常対応の傾向が強い状態（以 下 $\mathrm{N}>\mathrm{A}$ と略す), 残像法で異常対応と判定で きるタイプを異常対応の傾向が強い状態（以下 $\mathrm{A}>\mathrm{N}$ と略す）とした。また, 調和性や不調和 性の異常対応を示すものを異常対応（以下 A R $\mathrm{C}$ と略す）とし，検査に信頼性の得られなかっ たものを不明とした。

また，ボツリヌム注入前後に眼位の安定化を はかるために，多焦点眼鏡の装用，縮瞳剤によ る薬物療法, プリズム療法などの視能矯正を行 った。

\section{III. 結果}

1 . 眼位変化

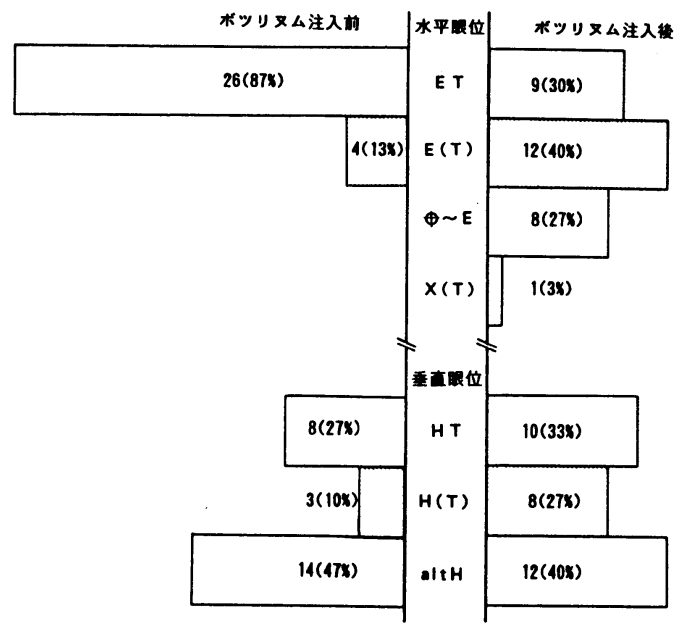

困 1 ボッリヌム注入前後の眼位変化（30例）

ボッリヌム注入前後の眼位変化を図 1 に示す。 水平方向の眼位ずれは, 注入前に顕性内斜視が 30 例中 26 例 $(87 \%)$, 内斜位一斜視 4 例 $(13 \%)$

であったが，注入後 9 例 (30\%) に斜視が残存 し, 12例 (40\%) は斜位一斜視に改善, 8 例 $(27$ \%)は正位から斜位に改善した。1例のみ外斜 位一斜視となった。垂直方向の眼位ずれは，上 斜視または上斜位一斜視の合併例は注入前30例 中11例 (37\%) であったが，注入後18例 (59\%) と増大が認められた。交代性上斜位は注入前 14 例から注入後12例に減少した。

\section{2. 網膜対応の変化}

ボツリヌム注入前後の網膜対応の変化を図 2 に示す。注入前に N R C または N > A を示した 症例は30例中 9 例 $(30 \%)$ であったが, 注入後 は18例 (60\%) と増加した。A R Cを示した症 例は, 注入前 6 例から注入後 2 例に減少した。

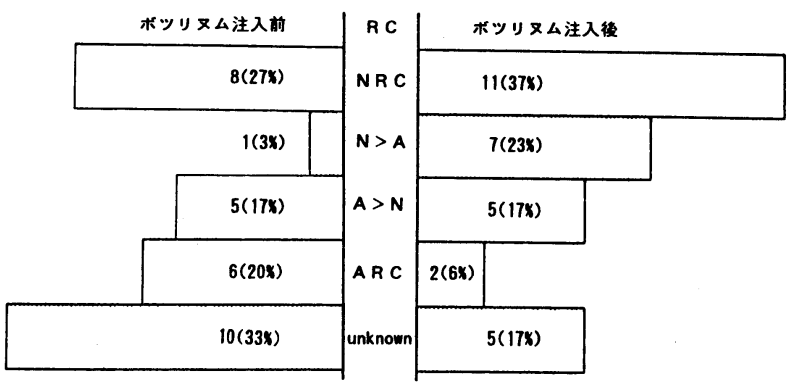

図 2 ボッリヌム注入前後の網膜対応の変化

(30例)

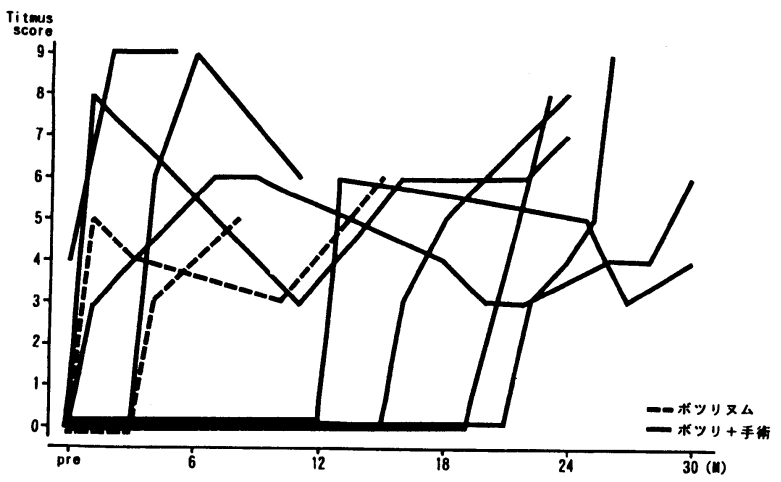

図 3 両眼視機能獲得経過 (10例)

破線 : ボツリヌム療法のみ行った症例

実線 : 斜視手術後にボツリヌム療法を行った症例

\section{3. 両眼視機能獾得とそのプロセス}

ボッリヌム注入後の両眼視機能獲得状態を, 表 1 に示す。両眼視機能良好例（チトマススコ ア7 9/9) は30例中 5 例 $(17 \%)$, 改善 (4 6/9) 5 例 $(17 \%)$ ，不良 $(0 \sim 3 / 9)$ 20例 (66\%) であ った。そのうち, ボッリヌム療法のみ行った 6 例のうち, 改善 2 例, 不良 4 例であり, 良好例 はなかった。経過観察期間は平均 14 加であっ た。また斜視手術後にボツリヌム療法を行った 症例の経過観察期間は, 平均20か月であった。

両眼視機能を獲得できた良好・改善例10例の 獲得経過を図 3 に示す。注入後 6 か月以内に両 
表 1 ボッリヌム注入後の両眼視機能獲得状態（30例）

\begin{tabular}{|c|c|c|c|c|c|}
\hline \multirow{2}{*}{$\begin{array}{r}\text { チトマス } \\
\text { スコア }\end{array}$} & \multicolumn{2}{|r|}{ ボツリヌム (n=6) } & \multicolumn{2}{|c|}{ ボツリ+手術 (n=24) } & 計 $(n=30)$ \\
\hline & 成績 & 経過観察期間 (M) & 成績 & 経過観察期間 (M) & 成績 \\
\hline $\begin{array}{l}\text { 良 好 } \\
(7 \sim 9 / 9)\end{array}$ & 0 & 0 & 5 & 19.5 & $5(17 \%)$ \\
\hline $\begin{array}{l}\text { 改 善 } \\
(4 \sim 6 / 9)\end{array}$ & 2 & 11.5 & 3 & 23.7 & $5(17 \%)$ \\
\hline $\begin{array}{l}\text { 不 良 } \\
(0 \sim 3 / 9)\end{array}$ & 4 & 15.0 & 16 & 19.3 & $20(66 \%)$ \\
\hline
\end{tabular}

眼視を獲得した 6 例は, 注入前の積極的な視能 矯正によって, 両眼視の基礎を獲得していた症 例である。ボッリヌム療法のみ行った 2 症例は この中に含まれる。 1 年以上の期間を要した 4 例は, 注入前に両眼視の全く認められなかった 症例である。

\section{IV . 考按}

乳児内斜視は, 両眼視機能の獲得が困難とい われるが，今回内直筋の過緊張を認める乳児内 斜視にボッリヌム療法を行うことで，34\%に両 眼視機能が獲得できた。

ボツリヌム療法は筋の過緊張を弱め, 眼位を 変化させるが, 持続効果の得られない場合があ る。今回, 私共は, 平均 2.9 回の頻回少量注入 により注入後 3 か月以上を経ても, 70\%に正位, 斜位または斜位一斜視への安定した眼位改善が 得られた。また,このうち 1 例のみ外斜位一斜 視となった。

ボッリヌム注入により，一時的に眼位が大き く変動することがあった。注入後 7 ～10日目の 最大効果出現時に二次性外斜視が26例 $(87 \%)$

に生じたが，この眼位過矯正が生じた症例には 網膜対応の変化が認められた。網膜対応は, ボ ツリヌム療法によって $60 \%$ に正常対応化を認め た。これは, ボッリヌム注入後の眼位変動に関 連すると思われる。すなわち一時的な眼位過矯 正効果によって異常な力向感覚が打ち消され， さらに頻回注入によって安定した良好な眼位が 保持できると,ここに新たな視方向の確立が生
まれ，正常対応化による感覚異常の改善が起こ ると考えられる。ボッリヌム療法による眼位の 過矯正は，一過性であり，感覚運動異常をもつ 斜視の治療には有用と考えられる。しかし，今 回23\%にはAR Cが残存した。A R C の改善で きなかった 2 例のうち 1 例は, 調和性異常対応 を示し, 注入開始後20か月を経ても感覚異常の 改善が認められなかった。調和性異常対応の確 立した症例は, 長期間の経過観察と今後の検討 が必要と思われる。

ボツリヌム療法は, 眼位の矯正による感覚異 常の改善によって, 両眼視機能の獲得を導くと 思われる。両眼視機能の獲得状態をみると, ボ ツリヌム療法のみ行ったグループは, 注入後の 経過観察期間が平均 14 かと短期間で両眼視機 能獲得は不十分であった。しかし，それでも注 入前の積極的視能矯正によって, 両眼視機能の 基礎を獲得していた症例は, 早期に眼位が安定 し, 両眼視機能の改善が認められた。一方, 斜 視手術後にボツリヌム療法を行ったグループで は, 良好な両眼視機能獲得例が多かったが, 注 入後の経過観察期間が平均20か月におよび, 経 過観察期間の違いが良好な成績に関与している と思われる。このグループにおいても積極的な 視能矯正管理を行っている症例は, 両眼視機能 の早期獲得が認められた。早川ら $\left.{ }^{9}\right)$ は 5 年以 上の視能矯正管理を行った乳児内斜視の $67 \% に$ 良好な両眼視機能が獲得できたと報告している。 長期間眼位の綿密な調整を行うことが自然視下 の両眼視訓練となり, 両眼視の作動を生じさせ 
ることができると考えられた。

\section{$\mathrm{V}$. 結 論}

内直筋の過緊張を認める乳児内斜視は，ボツ

リヌム療法による頻回にわたる眼位矯正を綿密 に行うことで, 良好な両眼視機能獾得への始動 ができると考えられる。

\section{文献}

$1)$ Scott, A. B., Rosenbaum, A. L. and Collins, C. C. :Pharmacologic weakening of extraocular muscles. Invest. Ophthalmol., 12 : $924-927,1973$.

2 ) Scott, A. B. : Botulinum toxin injection into extraocular muscles in alternative to strabismus surgery. Ophthalmalogy, $87: 1044-1049$, 1980.

3 ) Rosenbaum, A. L., Scott, A. B. : Botulinum toxin therapy in the management of strabismus and lid disorders. The Western Journal of Medicine, $144: 456$ - 457, 1986.
4 ) Scott, A. B. : Botulinum toxin treatment of strabismus. Am. Orthopt. J., 35 : $28-29,1985$.

5 ) 岩重博康, 丸尾敏夫:ボッリヌム $\mathrm{A}$ 型毒素 (Oculinum)による斜視治療. 日眼, $90: 1366$ $-1374,1986$.

6 ) 木村久 : 斜視の外眼筋筋電困とボッリヌム毒 素療法. あたらしい眼科， $6: 1133-1143$, 1989 .

7 ）木村久, 簡井純, 他 : ボッリヌストキシン療 法と斜視手術ーボッリヌストキシンの注入量 の検討 - . 眼臨, 83:2298-2300, 1989.

8 ）木村久, 新井紀子, 他 : 斜視のボッリヌム療 法一下斜筋への応用. 眼科手術, $4: 747-$ 750, 1991.

9 ) 早川友恵, 深井小久子, 他: 釈児内斜視の長 期経過観察における両眼視機能の獲得につい て (第 1 報)。日眼, $94: 820-828,1990$. 